\title{
Genetically Modified Organisms and Their Impact on International Agricultural Trade: A Case Study on Soy
}

Paulo Ricardo da Silva Oliveira ${ }^{1}$; José Maria Ferreira Jardim da Silveira ${ }^{2}$.

\begin{abstract}
This paper discusses the introduction of genetically modified (GM) seeds in agriculture and their impact on the modus operandi of international trade of agricultural commodities. The central argument in this paper is that the commercial rejection by some markets, especially in the European Union, resulted in broad market share restructuring of the three largest international soy exporters: the United States, Brazil, and Argentina. These findings came as a result of trade flow analysis, taking into account the source and destination of soy in the soy trade using the quantitative Constant Market Share method.

Taking into account that at the time of the study there were no legal trade barriers put up by the European Union, which was resistant to the use of Monsanto's herbicide-tolerant soy (GTS-40-3-2), it is assumed that the effects resulting from its commercial rejection were due to demand factors and not for any official trade ban. It is concluded that technology adoption caused changes in factors that led to export growths. However, despite changes in market share, the globalization effect prevented exporters from incurring greater trade losses since they always had the option of moving their products to markets with lower levels of "hatred".
\end{abstract}

Keywords: GMO Trade; Technological Diffusion; Technological Innovation and Trade; Constant Market Share Analysis; GMO Economic Impacts.

${ }^{1}$ Docente Extensionista do Centro de Economia e Administração da PUC-Campinas. ORCID: https://orcid.org/00000003-1181-2867

${ }^{2}$ Professor do Instituto de Economia da Unicamp. 


\section{Organismos Modificados Genéticamente Y Su Impacto En El Comercio Agrícola Internacional: Un Estudio De Caso En La Soja}

\section{Resumen}

Este artículo discute el ingreso de semillas genéticamente modificadas (GM) en la agricultura y su impacto sobre el modus operandi del comercio internacional de productos agrícolas. El argumento central de este trabajo es que el rechazo comercial por parte de algunos mercados, sobre todo en la Unión Europea, mostró una amplia reestructuración de la cuota de mercado de los tres mayores exportadores internacionales de soja: Estados Unidos, Brasil y Argentina. Estos hallazgos se produjeron como resultado del análisis de las corrientes comerciales, teniendo en cuenta el origen y el destino de la soja comercializada, utilizando el método cuantitativo de análisis constante de las cuotas de mercado (Constant Market share, CMS).

Teniendo en cuenta, que en el momento del estudio no hubo barreras comerciales legales puestos por la Unión Europea, que era resistente a la utilización de la soya tolerante a herbicidas de Monsanto (GTS -40-3-2), se supone que los efectos derivados de su rechazo comercial se debieron a factores de la demanda y no de cualquier prohibición del comercio oficial. Se concluye que la adopción de la tecnología provocó cambios en los factores que daban lugar al crecimiento de la exportación. Sin embargo, a pesar de los cambios en la cuota de mercado, el efecto de la globalización impidió que los exportadores incurrieran en mayores pérdidas comerciales ya que siempre tenían la opción de trasladar sus productos a los mercados con menores niveles de "rechazo".

Palabras Clave: Comercio Internacional de OMG; Difusión Tecnológica; Innovación tecnológica y el comercio; Análisis de cuotas de Mercado Constantes; Impactos económicos de Transgénicos. 


\section{Les Organismes Génétiquement Modifiés Et Leur Impact Sur Le Marche Agricole International}

\section{Resume}

Cet article parle de l'introduction des graines génétiquement modifiées dans l'agriculture et de leur impact sur le mode opératoire du commerce international des produits issus de l'agriculture. Le point majeur développé dans cet article est que les interdictions émises sur certains marchés, surtout au sein de l'union européenne, provoquent un changement dans la répartition des parts de marchés des trois plus gros exportateurs de soja: Les Etats Unis, le Bresil et l'Argentine. Ces conclusions sont le résultat de l'analyse des flux commerciaux, en tenant compte de la source et la destination du soja dans le commerce de soja en utilisant la méthode part de marché constante quantitative (Constant Market share, CMS).

Il est important de préciser qu'au moment de l'étude, il n'y avait aucune barrière commerciale mises en place par l'union européenne. Néanmoins, celle ci était tout de même réticente à l'utilisation du pesticide GTS-40-3-2 de l'entreprise Monsanto. Il est clair que la cause principale de l'interdiction sont facteurs de demande et non une volonté d'imposer des barrières commerciales. Le résultat est que cette adoption a causé des dommages majeures à l'augmentation des exportations. Néanmoins, malgré ces changement sur les marchés, la mondialisation a permis aux exportateurs de limiter les pertes en leur donnant l'opportunité de déplacer leur produit sur des marchés moins sujets aux variations de l'opinion publique.

Mots-clés: Commerce International des OGM; Diffusion Technologique; Innovation Technologique et le Commerce International; Constant MArket Share; Impacts économiques des transgéniques. 


\section{Organismos Geneticamente Modificados e seu Impacto no Comércio Agrícola Internacional: Um Estudo de Caso da Soja}

\section{Resumo}

Este artigo trata da inserção das sementes geneticamente modificadas (GM) na agricultura e o seu impacto no modus operandi do comércio internacional de commodities agrícolas. $\mathrm{O}$ argumento central deste artigo é que a rejeição comercial por parte de alguns mercados, especialmente a União Europeia (UE), resultou em ampla restruturação das parcelas de mercado dos três maiores exportadores mundiais de soja: Estados Unidos, Brasil e Argentina. Esta restruturação é corroborada pelos resultados obtidos da análise dos fluxos de comércio, considerando-se origens e destinos do comércio de soja, por meio do método Constant Market Share (CMS).

Considerando-se que durante o período analisado não houve barreiras legais ao comércio de OGM, impostas pela UE, a qual se mostrou resistente ao consumo da soja GM (GTS-40-3-2), assume-se que os efeitos resultantes de tal rejeição comercial estão ligados a fatores de demanda e não a proibições ou barreiras diretas ao comércio. Conclui-se que a adoção tecnológica alterou os efeitos que guiaram o aumento das exportações ao longo do tempo. Entretanto, a despeito das mudanças nas parcelas de mercado, o efeito globalização impediu que exportadores incorressem em maiores perdas comerciais, uma vez que eles sempre tiveram a opção de exportar seus produtos para mercados com menores níveis de aversão.

Palavras-chave: Comercio Internacional de OGM; Difusão Tecnológica; Inovação Tecnológica e Comércio Internacional; Constant Market Share; Impactos Econômicos dos Transgênicos.

JEL: F13, F14, Q13

\section{Introduction}

According to data from FAO collected in 2013, soybean's share of harvested area of the world's primary agricultural crops increased from $2.5 \%$ in 1961 to over $7 \%$ in 2010 . In 2010, absolute figures of worldwide harvested area of soybeans exceeded 102 million hectares. Same year production exceeded 261 million tons. Part of the growth was driven by some factors more or less related among them, such as world income growth, new uses - biofuel for instance -, increased meat intakes, entry of new importers into the global markets, among others. Moreover, along with the growth in soybeans production, since 1996 and lasting until today, GMOs have been increasingly adopted in spite of meeting strong opposition in some markets. 
International trade became an arena of great conflict between producers and importers of agriculture products, well-represented by two large economies with conflicting positions toward GM-food/feed production and commercialization ${ }^{3}$ : The United States of America (USA) and the European Union (EU). On the one hand, being a large agricultural producer and exporter as well as a major player in farming technology, the USA advocated for wide and free diffusion of GM seed technology and trade of its products. On the other hand, made up of Member States that are net importers of food, the EU has opposed the unrestricted adoption and trade of GM-food/feed, declaring that the high level of uncertainty involved required precautionary measures. This conflict is reflected in trade sanctions that stem from different countries' regulatory posture.

Since this conflict is between importers and exporters, official trade bans would make a good starting point for an impact analysis on actual GM trade, in the context of how and why GM products are rejected. However, this approach will be defined as "legalistic" and does not apply to the case of GM soy, once soybean trade was impacted globally, in spite of importing markets maintaining official bans to GM-trade.

This paper shows that the commercial rejection of GMOs initially caused a strong and accelerated restructuring of trade flows, changing market shares of the largest global producers in terms of source and quantity. The three major GM agricultural commodities, soy, corn and cotton, are also amongst the most commercialized, highlighting the potential impact that high levels of "hatred" toward technology offers for exporters. Soybeans are the world's most widespread GM crop, representing 50\% of all global GMO production, one of the reasons that justify this study focus on this particular crop. Moreover, the international soybean market underwent very particular conditions between 1996 and 2005. While US and Argentina allowed adoption of technology already in mid-1990s, in Brazil, production was legally approved only in 2005. The concentrated international supply and diverse international demand gave rise to a particular dual-market system. It means that traditional in-flows and out-flows have changed accordingly to the source of exports along with new consumer preferences in the destination country.

Therefore, the central aim of this paper is to shed lights on to the following question: How GM-food/feed technology impacted on trade flows taking into account the nature of the dual-market system? To this end, a Constant Market Share method (CMS) was employed. CMS, by assuming constant trade flows, breakdown any increase or decrease in exports into three distinct effects: growth of global imports, growth of destinations imports and competitiveness effect. In this particular case, competitiveness will be credited to the adoption or non-adoption of GM-food/feed technology.

\footnotetext{
${ }^{3}$ Similar to other authors we assume that trade rules are endogenous leading importers to adopt tougher stances on GMtrade, while producers tend to take more pragmatic measures (see Borges, 2003; Oliveira, 2012; Paarlberg, 2001; Vigani et al., 2012).
} 


$\mathbf{R} \sum \mathbf{S}^{[2018]} \quad$ V.20, n.41

This paper is split into five sections in addition to this introduction. In the following section, a literature review is carried out. In the third, a brief review of regulation of major importers of soybeans is introduced. In the fourth, method and data source are discussed.

Results from CMS are brought together in the section five, and lastly, section six brings the final remarks.

\section{Literature Review}

The literature focused on the dual-market systems and its impacts on trade flows from the perspective of source and destination is surprisingly concise. Economic debate on GMO-trade has been focused on price adjustments or national and multilateral regulation analysis instead of formal trade flow analysis. The few empirical studies on the field focused on regulation gaps and impacts on trade flows estimating losses in market share. Mostly, these studies employed more or less conventional gravity models to estimate impacts.

Indeed, the standardization versus differentiation of international trade basis, including regulatory issues, has been a particularly important starting point to address changes in trade flows. It can be assumed that the goal of standardization is to realize scale effects of world product mandates (Feinberg, 2000), reducing transaction costs and risks or maximizing profits (III \& Kashlak, 1999; Isaac, Perdikis, \& Kerr, 2004; Meyer, 2001; Rugman, 1976). Achieving these benefits requires the centripetal forces of international convergence, including production and process standardization (Griffith, Hu, \& Ryans, 2000). Recent research has focused on the general challenges facing the international standardization of technology, as well as the challenges facing the international standardization of biotechnology (Madhok \& Osegowitsch, 2000). From a neoclassical perspective, it can be said that competing with the centripetal forces of standardization are the countervailing centrifugal forces of public and private policies that threaten the scale benefits by fragmenting foreign markets (Isaac et al., 2004).

Vigani et al. (2012) performed a gravity model to analyze the impact of technology on bilateral trade in 2005, 2006 and 2007. The gravity variable is the gap between the regulatory frameworks of trade partners measured by an index estimated by the authors. The magnitude of the estimated coefficient implies that one standard deviation decreases in the GMO dissimilarity index $(=0.188)$ increases exports by $33 \%$, all else remaining equal. Thus, the effect is not only statistically significant but appears also relevant from an economic point of view. Moreover, the results suggest that labeling is the dimension most detrimental to trade followed by the approval process and traceability. 
Regarding detrimental variables impacting on trade, it is important to say that some studies point to low-level presence of unapproved GM material and asynchronous ${ }^{4}$ approval as key factors in this field (see Stein \& Rodriguez-Cerezo, 2009). Asynchronous approval, however, may be seen as a short-term type of regulatory distance, impacting on dissimilarity index.

Moschini (2004) $)^{5}$ developed a partial-equilibrium model to analyze implications from the introduction of genetically modified products into international markets. Results show that by imposing such a regulation (mandatory labeling) GM imports into Europe decrease. In other words, labeling could become a ban on imports depending on the level of segregation costs.

Disdie \& Fontagné (2009) studied the impact of moratorium of EU and rejection of other European countries on the exports of complainants (Canada, Argentina and US) and noncomplainants in a WTO dispute. For all products, estimated coefficients on the "EU moratorium and/or product-specific measures" variable are negative and statistically significant. As a result, this econometric specification shows that EU measures on GMOs reduced Argentina, Canada and US exports of maize seeds by $89.4 \%$ on average. Regarding national bans, it appears that only the Austrian ones on maize (seeds and other) and the Italian one on maize seeds do not have a significant impact. All other national safeguard measures affected Argentinean, Canadian and US exports. However, the authors did not analyze soybeans trade because they prior denied that any impact occurred in the soybean market, claiming that this was the only crop that was approved before the de facto moratorium initiated in $1998^{6}$.

Anderson \& Jackson (2004), by using a GTAP model with neoclassical closure, pointed out that since 1998 when the EU implemented its moratorium, GM adopting countries have lost EU market share to GM free suppliers, particularly Brazil for maize and soybean and Australia and Central Europe in the case of Canola. For developing countries, their results show that the EU moratorium benefits food-importers (Japan and Korea), because of an improvement in their terms of trade. Policies potentially provide a mechanism for accommodating consumers' preferences for non-GM food, although not without some cost to the global economy in terms of necessary segregation and identity preservation (IP) systems (Oliveira, Silveira, \& ALVIM, 2012).

\footnotetext{
${ }^{4}$ Asynchronous approval means the short-term gap between years of approval across different countries. Long-term gaps may be seen as asymmetric approval.

${ }^{5}$ In the model, innovators hold property rights, farmers are competitive, and some consumers believe that GM food is inferior in quality when compared with traditional food. Identity preservation generates additional costs to the whole market (GM and traditional) via segregation costs.

${ }^{6}$ The EU pressured by national interest groups did not approve any new event between 1998 and 2003. This period was defined by literature as the de facto moratorium. The controversies and conflicts that arose from this period were discussed at the DSB (Dispute Settlement Body) under WTO.
} 
On the other hand, there are evidences that Canada's oilseed rape and US corn sales to the EU were successfully shifted to other markets. Market losses occurred but only over a short period, and globalization quickly offered new export opportunities to GM producers preventing exporters incurring in major economic losses via demand diversification (Smyth, Kerr, \& Davey, 2006; Stein \& Rodriguez-Cerezo, 2009). There are also concerns in literature about bans and technology diffusion especially for the case of developing countries. The general idea is that GM technology diffusion was hampered to a certain extent by major markets rejection (Anderson, 2010).

Based on this concise literature, one can say that there is consensus about the fact that GM technology affected trade flows. However, studies diverge regarding the nature and extent of these impacts. The major part of studies recognizes that labeling plays an important role to explain trade adjustments. Indeed, labeling is the mechanism that enables product differentiation, and, for some authors the unique mechanism able to avoid the well-known problem of market for lemon describe in the Akerlof's seminar work (Moschini, 2004) ${ }^{7}$. Therefore, regulation may be needed to maintain product diversity, which typically can be efficiently achieved with private certification schemes. On the other hand, depending on the level of added costs mandatory labeling may represent a non-tariff barrier to trade (Oliveira \& Silveira, 2013)

Finally, studies focusing on official bans, tariff trade barriers or moratoriums, like Disdier and Fontagné (2009) ${ }^{8}$, do not take into account effects on trade of crops officially approved for importation. This legalist vision - accurate for author's proposal -ended up faultily guiding the focus of some studies that sought to analyze the impacts of regulation on trade in these two decades of GMO developments.

This paper contributes to the literature by adopting a different methodology and making use of different empirical data to address a similar problem. As far as we noticed there are no prior analyses making use of the same data and method. Moreover, we also add by changing the focus to a "seemingly" unaffected crop, by adopting a less legalist approach.

\footnotetext{
${ }^{7}$ If the superior product cannot be distinguished from the inferior one, the pooled equilibrium likely to emerge in the market would contain too high a proportion of low-quality product.

${ }^{8}$ Authors took into consideration only crops in the context of WTO disputes, i.e., non-approved crops that claimers judged to be impacting their exports. It is important to note that the for the aim of their study, it is to say, to measure economic impacts of official bans, not considering soybeans isn't a big deal. On the other hand, studies focused in general impacts of GM on trade should also consider approved crops since evidences shows that they also were impacted.
} 


\section{The Asian and European Markets: A Brief on Approvals and Labeling Regimes}

\subsection{European Markets}

The European Directive 90/220/ECC9 - on the deliberate release into the environment of genetically modified organisms - was based on the precautionary principle recommended by OECD (1986) to regulate the releases of genetically modified organisms. It represents the minimal consensus among member stating that the introduction of genetically modified organisms should be regulated to obtain harmonization between members of the Union and alignment with international standards and principles. Lack of consensus, however, emerged when European Commission announced in its communication of December, 1996 the review of the above mentioned directive, which concerns the deliberate release of GMO for market proposals (Schomberg, 1998).

In 2004, when regulation demand on GMO importation intensified, the labeling and traceability of GMOs was implemented under EC 1829/2003, which replaced the previous regulation ${ }^{10}$. The other European countries ${ }^{11}$ that do not submit to official EU standards, have also hold a number of measures contrary to GMO technology. Actually, in some cases, they are even more restrictive than the EU countries in terms of national biosafety regulations. Therefore, these countries will be considered jointly in this analysis.

EU regulation provides general rules for research, trade and production in member states. Taking into consideration that for this scope labeling is the mechanism that enables product differentiation of approved crops, the issues of new event authorizations and processes of labeling and traceability are of most importance to this study (see also Oliveira et al., 2012; Oliveira \& Silveira, 2013).

In the EU, the approval process is the same for GMOs or products containing GM ingredients for any purpose, such as processing, food and/or feed. Traceability and labeling of GMOs are mandatory. Labeling rules define which products must be labeled as "contains GMOs". The product must be labeled regardless of the degree of processing, and when sold without packaging, for example, in restaurants, the information "contains GMOs" should be visible ${ }^{12}$. Any product with an

\footnotetext{
10 According to Silveira \& Borges (2007), the EU adopted a set of regulatory actions with the deliberate intention of postponing decisions rather than building the basis of rules and standards to minimize the potential impacts of innovation. This is evident in the production moratorium which lasted for several years in several member states. Anderson, (2010) suggests that European producers would be in a worst-case scenario if there were no barriers to GMO technology adoption when compared to a world without agricultural biotechnology.

${ }^{11}$ The EU is made up of countries that held opposite positions on GM technology during this period, although there are member countries that are less contrary to this technology. It is also worthy to note that there is lot of works dealing with differences between European countries. For simplicity this analysis focuses on the general impacts considering Europe as a more or less homogenous group.

12 It is evident that alignment with this particular requirement is difficult to be followed-up.
} 
adventitious level of GM ingredients greater than allowed should be labeled as "GMO". Animal protein feed with GM products is the only exception to mandatory labeling norms. On the other hand, there are signs that voluntary labeling with the information "GM-Free" has been opening space for IP grains in feed sector.

Of course, when adventitious presence involves an event that is not authorized for consumption in the EU, the product cannot be placed on the market, despite being labeled. It is worth noting that the level of adventitious presence tolerated by the EU is the world's lowest. For products not approved the tolerance level is virtually zero $(0.1)$, while for approved products it is $0.9^{13}$.

In recent years, approvals of new soybean varieties for import have been made. Although not formally confirmed, there are indications that the EU approved new varieties because of the increasing scarcity of conventional crops is creating a production risk for the domestic livestock and processing industry (see Stein \& Rodriguez-Cerezo, 2009). Table 1, at the end of the paper, shows which GM soybeans were approved until 2010, the type of approval and the year in which approval was granted. Note that the approvals of new varieties took more than 10 years to occur as a result of de facto moratorium. ${ }^{14}$

In addition to regulation lateness the surveys on consumer opinions provide evidences of consumer opposition to technology in Europe. In November 2000, for example, the "Nordic Industrial Fund" conducted a survey in Denmark, Finland, Norway and Sweden on consumers' opinions about genetically modified foods and their derivatives. The survey found that conventional foods have benefits simply because they are not genetically modified ${ }^{15}$. A series of negative associations, such as "unhealthy products" and "great uncertainty about the risks" were attributed to GMOs (Grimsrud, 2004). The same author pointed out that the Norwegians, who the authors take as a sample for the European market, would be willing to buy a GM product at an average discount of $50 \%$ in price.

The results of another survey revealed that the highest level of formal education positively affects the consumer's acceptance in the same country, while women and older respondents reacted negatively. Curiously, self-declared awareness about the GM technology negatively affects the will to consume GM-food (Mccluskey, Grimsrud, \& Wahl, 2006). It could be evidencing that the way that the media has reported the issue contributed to the negative perception among European consumers (see Brossard, Shanahan, \& Nesbitt, 2007). Surveys on the EU27 revealed that

\footnotetext{
${ }^{13}$ This level can be a great problem to modern trade basis. The current logistic system for international transportation and storage of grains is based on scale gains, complicating identity preservation and maintenance of low levels of adventitious presence.

${ }^{14}$ For information about practical implementation of coexistence in Europe and their impact on production and trade see PRICE (2013).

${ }^{15}$ The assumption that the residual competitiveness effect of the method used well-represent technology divergence between sources of trade is also based on results from surveys of this type. They make explicit that GM food/feed are frequently considered inferior or equal to its traditional counterpart. Thus, traditional crops gain competitiveness simply because they are not genetically modified.
} 
Europeans are quite aware about GM issues. Results show that $46 \%$ of respondents talked about or searched for information occasionally, $9 \%$ talked about or searched for information frequently and $27 \%$ at least heard about GM-food. The same study also revealed that levels of technology support for food production in 2010 were low and decreasing when compared to surveys carried out in 2005. In 2010 , only $5 \%$ of respondents declared "totally agree" with technology and $18 \%$ declared that they "tend to agree". On the other hand, 33\% declared "tend to disagree" and 16\% "totally disagree"(Gaskell, Stares, Allansdottir, \& Allum, 2010).

However, empirical researches often point to a certain degree of inconsistences between public opinion and effective decreases in total intakes of GM-food/feed. These inconsistences may be related to the fact that consumers do not properly recognize labels (Noussair, Robin, \& Ruffieux, 2002). Finally, the role of retailers must be considered for the EU case. It is a fact that large retailers have been avoiding selling labeled products in order to avoid conflict with activists. This seemingly subtle effect may be affecting significantly the trade of GM food.

To sum up, in European countries most opposed to technology, producers see organic production as more promising and believe that the rules of coexistence will not be able to ensure good farming practices to maintain identity preserved. The presence of organizations such as Greenpeace and Friends of the Earth contributes to the formulation of the concept of "Frankenstein foods". In other words, politicians, policy makers, agricultural cooperatives and consumers share the same opinion, to say that, agricultural biotechnology creates uncertainties, offers no clear benefits, and therefore is not required (Gaskell et al., 2010).

\subsection{Asian Markets}

In the context of Asian regulation, the focus will be on China and Japan. Japan was selected by its great potential to influence decisions in other Asian countries. China, in turn, had a major impact on the restructuring of market share since it has significantly increased their intake of soybeans during the period analysis preventing exporters from incurring in major economic losses.

Japan has mandatory labeling and biosafety assessments procedures but considers that the products of biotechnology are of a distinct character to one another, establishing a series of exceptions according to end product. Roughly speaking, all GM food products, or which have been obtained by processes with GMOs and GM food additives, must undergo a prior risk assessment. In 2000, Japan implemented a regulatory body to govern the approval process for new varieties. The tests focus on the events unapproved in Japan and adopted a zero-tolerance policy for such events. When it comes to approvals of events intended for feed, the legislation is more permissive in the tolerance threshold for adventitious presence for these products, set at $1 \%$ for varieties not approved in Japan. Labeling ${ }^{16}$ is mandatory when DNA / protein GM is identifiable in the finished product or

\footnotetext{
${ }^{16}$ Japanese regulatory policy is pragmatic, when one considers that although the labeling policy is mandatory, it does not cover all products. Furthermore, the tolerance threshold for adventitious presence appears reasonable and consistent with the current logistics structure of the trade of grains (Carter \& Gruère, 2006).
} 
the GM ingredients constitute one of the three main components of the food. Products such as soy oil need not be labeled, unless the nutritional characteristics of food have been modified, but, other less processed products are often labeled ${ }^{17}$. The table 2 shows the approved GM varieties of soybeans in Japan.

When compared to other countries, Japan has among the greatest number of approvals for soybean varieties, including those that are nutritionally modified. The approval process depends on the product's purpose, so not all events undergo the same process. Although all the varieties have been approved for cultivation, according to data from the Biotechnology Industry Organization (BIO), so far Japan has not produced GM soybeans. As in Europe, the food industry and retailers have avoided selling products labeled as GM - but processed foods end up being excluded from the list of mandatory labeling.

On the other hand, the purpose of regulation in China is noticeably different from that observed in the EU and other countries opposed to GM technology. According to the National Biosafety Law, enacted in 1993, China aims to promote research in biotechnology, consider the adequate control of biosafety, ensure the maintenance of public health, prevent contamination of the environment and maintain the balance of biodiversity (Decree 304/2001).

In May of 2001, the Chinese State Council promulgated the "Regulation on Safe Administration of Agricultural Biotechnology", by Decree 304. This law replaces the regulations previously in place, fully regulating agricultural biotechnology in the country. The Ministry of Agriculture controls virtually the entire process of new approvals in the country. Some issues related to labeling, and more specific procedures for export and import, are decided by an inter-ministerial council formed by the State Council. Also, in 2001, the Ministry of Public Health promulgated the first guideline over GM food safety. These laws came into force in June of 2002, bringing a number of important deliberations, such as the requirement of field tests before market release, mandatory labeling, new standards for importation and exportation of GM food and rules for regional monitoring (J Huang, Yang, \& Yang, 2012).

As in Japan, the Ministerial Council created a list of products subjected to mandatory labeling. The criteria that guide the inclusion or removal of products from the list include socioeconomic factors, political goals and biosafety of the country. The regulation is defined by Decree 10 (CH7053) and the list includes soybeans, soybean meal and soybean oil. Currently, three GM soybeans have market approval in China, as seen in the table 3.

\footnotetext{
${ }^{17}$ It seems to be a trend that more processed products are less vulnerable to restrictive trade norms. It points out that strategies for exporting the processed grain may succeed, as example those adopted by Argentina.
} 
Note that the approvals of GM soybeans in China were delayed. This fact, when analyzed together with the results of this study, suggests that China imported GM soybeans from the United States, Argentina and Brazil even before the formal approval of the events. In 1993 regulation of imports was minimal; merely stating that the same rules applied to domestic biosafety would apply for imported products. However, no significant trade bans were in place for soybeans in this market during the period of analysis.

Although positive view and acceptance by Chinese society of GMO, it is worth noting that China's import approval process takes on average 2-3 years and can only commence when a submitter for import approval has already received full regulatory approval in their country of origin, intensifying negative impacts of asynchronous approval (J Huang et al., 2012).

Consumer participation in shaping the legal apparatus is also very incipient, making it easier for the government to implement standards from the top down, and so, reducing the importance of consumer opinion.

There are several studies focused on consumer opinion in China. They present significant divergence toward consumer acceptance in the country. On the one hand, a study carried out by Greenpeace (2004) claimed that GM foods were generally not accepted by Chinese consumers. On the other hand, some studies identified that Chinese consumers were willing to pay a premium for GM foods.

Mccluskey et al. (2006), for instance, analyzed the differences between the views of consumers in both China and Japan. Japanese consumers' attitude toward GM technology is closer to the attitude of European consumers than their Asian neighbor. They also were willing to buy a GM product if the discount on the final price of the product was, on average, $50 \%$. Variables such as knowledge of the subject, level of formal education, if the individual is female or in an older age group, directly affect the rejection of the product at an increasingly rate when compared with a sample of U.S. consumers. On the other hand, Chinese consumers would be willing to pay a premium of $38 \%$ to consume a variety of GM rice (Golden Rice) and 16.4\% for GM soybean oil. Although factors such as formal education and self-reported knowledge about the issue have negative impacts on their willingness to consume GM products, the values are always less significant than in Japan.

The information above points out that China has taken a pragmatic stance in favor of technology development, so that the media conveys a positive image of GMOs to the public (Jikun Huang, Qiu, Bai, \& Pray, 2006). This fact is very important in understanding the restructuring of trade, specifically the acceptance of grains from Argentina and US by this region of the globe.

The next section presents the data source and the methodology employed in this analysis. 


\section{Methodology and Data}

Constant market share (CMS) analysis is a technique for analyzing trading patterns and trends for the purpose of policy formulation. Based on an identity, the method is first and foremost a descriptive tool indicating whether or not a country's comparative export performance reflects changing in market shares or total market growth (Ahmadi-Esfahani, 2006). The traditional CMS model was first applied to the study of international trade by Tyszynski $(1951)^{18}$.

The CMS technique assumes that a country keeps constant it market shares being any change in the trade-flows a result of three basic effects ${ }^{19}$. Thus, the version of the method employed by this study is able to breakdown the growth or decline in exports by three distinct effects: growth of world trade, destination market and competitiveness. The world trade effect is nothing more than the share of growth that is explained by a general increase in global intake of a product or a basket of goods. Destination market is the portion of increase or decrease that can be explained by changes in the rate that a market imports a product or basket of goods in comparison with average rate of world import growth. Finally, the increases or decreases which are not explained by the above effects are attributed to the competitiveness effect. This residual effect can be explained by technological changes or other factors that cause changes in relative prices ${ }^{20}$ (Carvalho, 1995; P. R. S. Oliveira, 2012; Tomich \& Leite, 1999).

However, the shift from descriptive to diagnostic analysis is possible when there is a clear understanding of the theoretical model implicit in the presumption that market shares only reflect a country's international competitive performance.

\footnotetext{
${ }^{18}$ According to Ahmadi-Esfahani (2006), some recent studies still use the original model despite the problems widely documented by some authors (see Jepma, 1986; Oldersma \& Bergeijk, 1993; Richardson, 1971).

${ }^{19}$ It should be stressed that the factors just mentioned that bear upon the saleability of a country's exports are meant to describe the demand side of the phenomenon under study. Supply effects are undefinable. (ex 1. differential rates of monetary inflation 2. differential growth rates of available productive factors and the responsiveness of export supply to domestic supply of this factors; 3 . differential rates of productivity increases). These hypotheses are very likely to be true in respect to soy. Also, even though agriculture production is closely tied to natural forces, the random effects of nature were diminished by the three-year period approach used in the analysis. Another point is that soy trading usually involves future contracts, which forces quick adjustments due to international demand through transmission mechanisms. Producers do not produce first to sell later; they produce to fulfill future commitments.

${ }^{20}$ To assume competitiveness as a result of costs reductions can be considered a poor simplification. Leamer \& Stern (2006) make use of such a simplification while (Carvalho, 1995) amplifies the concept of competitiveness.
} 
At the heart of the diagnostic interpretation is the market-shares norm ${ }^{21}$, or the presumption that changes in market share, $s$, reflect purely competitive conditions. Perhaps the reason for CMS attracting greater attention over the question of interpretation than other methods (based on explicit empirical models) is that it is based on an identity and is not derived from an explicit theory (Ahmadi-Esfahani, 2006).

This model can be derived in different ways, so the knowledge of the subject and proposed objectives will indicate the best way. A useful framework to understand the model is presented by Leamer \& Stern (2006). In this study, we have used an adapted version of the technique to analyze a unique product. The general equation used in this analysis and adapted for one product can be written as follows:

$$
V_{i}^{\prime}-V_{i}=r_{i} V_{i}+\sum i \sum j\left(r_{i j}-r_{i}\right) V_{i j}+\sum i \sum j\left(V_{i j}^{\prime}-V_{i j}-r_{i j} V_{i j}\right)
$$

where,

- $\mathrm{V}_{\mathrm{i}}^{\prime}=$ amount of product $i$ exported in the initial period by country $x$;

- $\mathrm{V}_{\mathrm{i}}=$ amount of product $i$ exported in the final period by country $x$;

- $\mathrm{r}_{\mathrm{i}}=$ growth rate exports of product $i$;

- The subscript $j$ represents the markets of destination of goods $i$.

Thus, variations of $\mathrm{X}$ for exports $\mathrm{i}$, will be broken down into the following effects:

- $\quad\left(\mathrm{r}_{\mathrm{i}} \mathrm{V}_{\mathrm{i}}\right)$, world trade effect ${ }^{22}$;

- $\quad \sum \mathrm{i} \sum \mathrm{j}\left(\mathrm{r}_{\mathrm{ij}}-\mathrm{r}_{\mathrm{i}}\right) \mathrm{V}_{\mathrm{ij}}$, destination effect;

- $\sum \mathrm{i} \sum \mathrm{j}\left(\mathrm{V}_{\mathrm{ij}}^{\prime}-\mathrm{V}_{\mathrm{ij}}-\mathrm{r}_{\mathrm{ij}} \mathrm{V}_{\mathrm{ij}}\right)$, competitiveness effect.

This study considers the three major exporting producers / exporters of soybeans worldwide, which are also the biggest producer of GM crops, namely: The United States, Brazil and Argentina. Countries were considered separately generating three analyses results. As the destination market, countries were grouped according to their importance for understanding the regulatory questions examined. This division was made as follows and finds similarities between the regulatory stance of these countries, their importance in the global market and their relative importance compared to other countries in the same regional bloc. Table 4 shows the division adopted in this paper.

\footnotetext{
${ }^{21}$ An unambiguous interpretation requires the market- shares norm, which assumes that market shares are independent of total imports, prices are cost-determined, and the only source of product differentiation is in terms of country of origin.

${ }^{22}$ Because CMS's objective is to examine competitiveness, the standard should be the sum of all competitors of the focus country, and not the world exports (Richardson, 1971). In this case study, given the concentrated world supply, the difference between world exports and main exporters supply is insignificant.
} 
The period of analysis covers years between 1990 and 2009, split into 5 discrete periods of time. This choice is based on the events occurred in the development of technology as well as the theoretical orientation of the authors who used the method in order to prevent distortions in the analysis by abrupt changes in production as well as seasonal effects (see table 5).

The trade data was obtained from FAOSTAT database accessed in 2013 and comprises export quantity of soybeans ${ }^{23}$ in tons from US, Brazil and Argentina into the whole world - grouped in the basis aforesaid.

We believe that CMS analysis is able to yield quite precise hypotheses and, thereby, indicate the direction for further research using other quantitative as well as qualitative methods.

\section{Results}

This section introduces and discusses the CMS results. In addition, data on proportion of processed soy and on increases or decreases in outcomes are presented. Production and processing directly affect exports from a perspective of supply side. Although CMS deals with demand-side factors data on supply-side may support results explanation. Each period of analysis is compared to the preceding period.

We assume that technology contributed a lot to product differentiation, taking into account that, by foundation, commodities cannot be easily discriminated in equilibrium circumstances, among other factors and evidences discussed in prior sections. We also believe that competitiveness is always relative to target markets. In other words, if a destination market has no significant levels of hatred, technology can contribute to positive competitiveness effect resulting from efficiency gains.

European market and China, as we have highlighted, played key roles in market restructuration. From the perspective of consuming markets, it is clear that changes occurred in the traditional trade flows (see chart 1).

Even before the results analysis is possible to see that European imports from US began to drop in 1996, while China took part in such exports. United States lost over 13 billion tons of soybean sales in the European market after adopting technology. On the other hand, Brazil take over the European market especially after US adopted technology. This evident impact will be discussed in detail along with the analysis results below.

\footnotetext{
${ }^{23}$ At first, the fact that this analysis refers strictly to grain commerce could be considered a limitation. Any signs towards the export of the processed product could certainly cause a decrease of the product in natura. However, an analysis of the export compositions of soy complex during the period reveals that this substitution is only true for the Argentine case, mentioned on Period I of the analysis.
} 


\section{Period I - Partial Adoption}

During this period, large consumer markets like the EU started to develop rejection to genetically modified food/feed by means of implementation of new regulations ${ }^{24}$. In 1996, the end of period I, US and Argentina adopted technology for commercial production, while Brazil holds prohibition for GM production until 2005. Table 6 shows the results.

The effective growth of Brazilian soy trade reached over 5.6 million tons, or $57.57 \%$, from $1990 / 02$ to $1995 / 07$. Data show that the world trade growth can explain up to $51.10 \%$ of the export's effective growth. The destination effect was negative but weak, making evident that Brazilian exports were concentrated in less dynamic growth markets - when compared to world's average. This means that if they depended solely on the growth of absorption of the destination markets, Brazilian exports should have decreased by $(-3.89 \%)$. Indeed, $80 \%$ of Brazilian exports were concentrated in European markets, $7 \%$ in Japan, 3\% in China and 4\% in other Asian countries in $1995 / 07$.

Brazilian exports into Japan decreased by $7 \%$ while China and Latin America together increased their imports from Brazil by $5 \%$ from 1990/92 to 1995/97. On the other hand, exports into Europe remained almost unchanged. These subtle changes occurred at the same time of first commercial release of GM crops. Thus, from the export growth perspective, one can assume that Brazil didn't suffered effects of technology rejection by European markets during this period.

The competitiveness effect was predominant reaching 52.79\%. It may be already attributed to technology effect. Brazil, by not adopting technology strengthened the image of "GM-Free country". From data on Brazilian exports of soy it is possible to see that the country started targeting European markets even before the emergence of the dual-market system, in view of that, country may have delayed adoption as a way to maintain market shares, as theoretically predicted by Anderson (2010) and empirically verified by Oliveira, et al (2013).

As aforementioned, Argentina has distinct features in terms of productive structure and level of technology adoption when compared to competitors. Argentina's exports decreased 52.66\% during this period. Part of this drop was due to the replacement effect in the export mix, since in the same period the country greatly increased exports of soybean meal (48\%) - a trend continued during all periods, albeit much less pronounced.

\footnotetext{
${ }^{24}$ As seen before in this paper, EU regulation preceded the first commercial release of GM crops. It is also true for other European countries. Switzerland, for example, had put into force its first regulation in 1994.
} 
If not for the world trade effect (55.88\%), exports would have decreased even more - since considering the negative growth rate negative signs have positive impact. The competitiveness effect was the main effect (151.62\%), showing that country's exports, for a number of variables, included technology adoption, had substantial disadvantages when compared to other countries exports.

Destination effect also contributed to effective decrease but modestly, accounting for $4.26 \%$ of effective growth. Argentina exports were concentrated in Europe as well - 79\% in 1995/9725. It means that Argentina also showed prior signs of specialization in supplying European markets, however results analysis for next period show that it failed.

Contrary to Brazilian case, Argentina exports into Europe decreased by $2 \%$ during this period. Technology adoption and high levels of hatred in European markets once again can explain these destination changes. On the other hand, Asian countries and China accounted for $13 \%$ of Argentinean exports in 1995/07 signaling changes on target markets.

The United States succeeded in increasing exports by $44 \%$ during period I. However, contrary to what happen with Brazilian exports, the effect that most contributed effective growth was growth of world trade $(66.89 \%)$.

Although less expressive when compared to Brazilian figures, competitiveness effect was positive (38.20\%). The fact that US exports were already less concentrated in markets that developed high levels of hatred toward technology and the fact that rejection of U.S. soybeans will be better established in subsequent periods help to explain this positive result.

The destination effect was negative $(-5.89 \%)$, showing that the markets in which exports were concentrated had sluggish growth when compared with the rest of the world. Also, US exports were concentrated in European consuming markets, but in a smaller amount, reaching 34\% in 1995/97. However, exports into Europe as a proportion of total decreased by $11 \%$ when compared to $1990 / 92$ while China, Japan and other Asian countries, accounted for higher shares of US exports in $1995 / 97$, respectively, $14 \%$ and $15 \%, 13 \%$ of total. ${ }^{26}$

\footnotetext{
${ }^{25}$ Although Argentina's exports were concentrated in European markets the amount exported into Europe was very reduced when compared to Brazil and US exports into the same markets, as can be seen in chart 1 .

${ }^{26}$ Although Japan share in US exports kept high, it is important to note that they decreased by $6 \%$ from 1990/92 to $1995 / 97$.
} 
In sum, it is possible to see that even during the first adoption-stages competitiveness effect behaved differently across the countries. Taking into account high levels of specialization in mature markets - usually averse to technology adoption - competitiveness effect was more favorable to Brazilian exports, given that the country didn't adopted technology in the first period. On the other hand, US exports growth depended mostly on world trade growth effect and Argentina decreased exports mainly because of competitiveness effect.

\section{Period II - Segregated Market}

During this period Brazil supplied markets with conventional soy while Argentina and US advanced in technology adoption process. Although all these countries performed positive growth rates, they differed in terms of effects composition. Table 7 shows the results for period II.

Brazil exports remarkably grew by $178.85 \%$ during this period - over 27.6 million of tons. Competitiveness effect stands out again accounting for $69.47 \%$ of effective growth, showing that Brazil didn't face losses of competitiveness during this period as well. Instead, this effect is even more pronounced than in the preceding period. World trade accounted for $27.64 \%$ of effective growth. Once again destination effect is modest (2.89\%), but positive because of a noteworthy growth of exports into booming markets.

Exports into Europe, as a proportion of total, decreased from $80 \%$ to $61 \%$ from $1995 / 07$ to 2000/02. On the other hand, Brazilian exports into China, as a proportion of total, increased from $3 \%$ to $22 \%$ during the same period. ${ }^{27}$ These changes are more likely to be related to high level of economic growth of Asian economies than to decreases in European imports from Brazil. It is worth to note that changes occurred along with outcome increases.

Argentina exports also grew impressively (246.42\%), partly by comparison to the mediocre preceding period base (1995/97). The competitiveness effect (77.84\%) had a completely different value and sign at this time, leading to the assumption that technology have brought competitive advantage to Argentinean exports. Taking into account the positive destination effect $(2.10 \%)$ one may assume that Argentina's exports were significantly concentrated in booming markets.

Indeed, the shares of consuming markets as a proportion of total Argentinean exports totally changed during this period. The share of European markets decreased from $79 \%$ to only $14 \%$ from 1995/97 to 2000/02, while China and other Asian countries - Japan excluded ${ }^{28}$ - increased from $13 \%$ to $79 \%$. As seen before, Asian markets developed lower levels of hatred when compared to European countries. It explains the positive performance of competitiveness and destination effect in Argentinean exports. Lastly, world trade effect can explain up to $20.06 \%$ of effective growth.

\footnotetext{
${ }^{27}$ In 2000/02 Brazilian exports into other European countries reached a peak of 3\% as a proportion of total exports. It may be evidencing that this group developed the highest levels of hatred when compared to member states of EU.

${ }^{28}$ There are no entries for Argentinean exports into Japan during these periods.
} 
Lastly, the US copes with a huge decrease in the growth rate of exports during this period. The ordinary effective growth of $11 \%$ was chiefly based on world trade growth $(442.96 \%)$. The negative and strong competitiveness effect (-389.30\%) indicates that lack of competitiveness of U.S. products worsened. In the same way, the positive destination effect $(46.34 \%)$ shows that the destination markets for U.S. soybeans had most dynamic growth, when compared to world growth, unlike the previous period when most of the exports were concentrated in the European market.

Since 1990/92, US exports into Europe and Japan ${ }^{29}$ have been decreasing as a proportion of total. On the other hand, they have been increasing in China and other Asian markets reaching 40\% in 2000/02. It suggests that concentration in European markets (23\% in 2000/02) and Japan (13\% in 2000/02) was able to drop down competitiveness effect. Likewise, exports amount into booming Asian markets was able to make destination effect positive.

To sum up, this period is the one that best support our hypothesis of trade impacts linked to technologies adoption. Brazilian exports increased significantly even compared to the high rate of growth of preceding period and this growth was clearly based on competitiveness effect. On the other hand, US faced mediocre export growth that can be explained negatively by competitiveness effect - it is to say, that the country lost competitiveness - and positively by world trade effect. Argentina's effects corroborate that competitiveness effect is relative to level of hatred in destination markets. This country increased exports based on competitiveness effect even after adopting technology.

\section{Period III - Full Adoption}

As seen in literature review, researches on consumer opinion shows that perception regarding technology remained the same or worsened during this period. However, supply conditions faced rapid and evident changes.

Since 1998, Brazil has approved the cultivation of Monsanto's herbicide-tolerant soybean (MON40-3-2). Despite the fact that commercial cultivation only took place after the approval of the National Biosafety law of 2005, this attitude was a clear sign toward possible change in the national production conditions. At the same time, the UE abandons the 1998 de facto moratorium and approves the EU Directive 1829/2003 on Genetically Modified Food and Animal Feeds. All these factors together, among others, help to explain the subtle decrease in the value of competitiveness effect in Brazilian exports. Table 8 shows the results.

\footnotetext{
${ }^{29}$ In spite of decreasing Japan shares in US exports, US still holds the largest shares in Japanese markets when compared to shares of Brazil and Argentina. It may be reflecting trade agreements effects.
} 
The effective growth of Brazilian exports reached over 23 million tons $(54.39 \%)$ from 2000/02 to 2004/06. The competitiveness effect accounted for $67.05 \%$ of effective growth confirming continuity of this effect on Brazilian exports at least until 2004/06. However, in comparison with the last period, competitiveness effect value decreased importance while word trade effect increased. The destination effect was negative $(-4 \%)$ in spite of noticeable market diversification. In 2004/06, China accounted for 38\% of Brazilian exports while Europe accounted for $45 \%$. Concentration in European markets help to explain positive competitiveness effect and negative destination effect. Asian markets also performed lower rates of importing growth in this period. The growth of international soy trade contributed to effective growth by $36.95 \%$.

The effective growth of Argentina exports was 37.98\%, much lower than that of preceding period. Again, the effects of world trade (52.81\%) and competitiveness (52.93\%) were the main factors responsible for this performance.

Destination effect was negative, accounting for $-5.73 \%$ of effective growth. More than $90 \%$ of Argentinean exports were concentrated in China and other Asian countries in 2002/04, but these countries failed in growth exports above the world average.

US exports decreased by $(-5 \%)$ during this period. The world trade effect largely prevented an even greater decrease $(-401.96 \%)$. On the other hand, the destination effect contributed to this decrease by $43.53 \%$, as well as the competitiveness effect by $458.43 \%$.

US partial concentration in markets such as Europe and Japan (24\% in 2004/06) explain a lot of negative competitiveness effect and part of negative destination effect. The slowdown in the rate of importation growth in China and other Asian countries also contributed to negative destination effect since 53\% of US exports were concentrated in these countries during 2004/06.

In sum, this transition period gives signs that some trends in effects behavior started reversing. Competitiveness effect lost a small importance to explain effective growth of Brazilian exports although this effect still explains the major part of effective growth of the same country. Argentina faced similar changes in effects composition, also signaling a loss of relative importance of competitiveness effect. Lastly, US still face consequences of competiveness losses related to technology adoption and markets aversion to GM food/feed.

\section{Period IV -Post Adoption Period}

Finally, when Brazil officially adopted the technology in 2005, it put an end to the welldefined borders of segregated market. The comparison between the Full Adoption Period and the Post Adoption Period reveals features of a more complex market, i.e., all the major producing countries adopted technology and segregation mechanisms become more uncertain. 
In 2004/06, Brazil enacted interim measures to increase GM soy areas by more than $30 \%$. Virtually, all soybeans exported from Rio Grande do Sul State during this period were GM, suggesting that GM soy was exported to the EU and other destinations without being labeled, given that crop segregation was just beginning at that time. Table 9 shows the results.

The rate of effective growth of Brazilian exports was 15.24\%. Not surprisingly, after Brazil has seen a rapid increase the rate of technology adoption the competitiveness effect became negative $(-39.47 \%)^{30}$. As competitors, Brazilian exports grew mainly due to the world growth effect $(151.41 \%)$.

China becomes the main destination accounting for 51\% of Brazilian exports in 2007/09. Europe, however, still holds $37 \%$ while other Asian countries accounted for $8 \%$. During this period, the entire world faced the effects of the financial crises, being Europe one of the most affected economies. This fact may explain higher and negatives destination effect values.

Argentina exports grew at the rate of $14.42 \%$, also mainly due to growth in world trade $(159 \%)$. The destination effect was negative $(-12.62 \%)$ and lackluster when compared to the competitiveness effect (-47.34\%), which was also negative. China and other Asian countries, without Japan, accounted for $84 \%$ of Argentinean exports in 2007/09. The reasons behind reversal of competitiveness effect are indefinite but it may be related to efficiency gains in Brazilian production after the technology adoption, since countries compete in the same markets.

US exports faced an expressive effective growth of $31 \%$, also mainly due to the world trade effect $(73.38 \%)$. The positive competitiveness effect $(32.41 \%)$ points out to annulment of disadvantage of exports over the competitors. US exports were mainly concentrated in China (55\%), other Asian countries (9\%), Europe (10\%) and Japan (8\%) in 2007/09. Once again, the negative competitiveness effect can be explained by slowdown in growth of Asian importing rates. Competitiveness effect, in turn, is explained by the loss of competitive advantage of Brazilian exports and low levels of hatred in markets that US exports are concentrated.

To sum up this final period of analysis is marked by the end of advantages related to the later adoption of GM technology by Brazil. Effects composition shows that US reached better relative competitiveness when compared to competitors and previous periods. Argentina also suffered the annulment of competitiveness advantage. In the absence of significant differences to discriminate the product by country of origin, effects suggest that export growth is depending on factors not related to technology adoption.

\footnotetext{
${ }^{30}$ According to estimates the proportion of GM soy as a total of soy harvested reached more than $90 \%$ in $2012 / 2013$ (Celeres, 2012). But it is important to note that informal estimates made by CEOs in trading companies operating in Brazil are higher, on average $80 \%$ in 2010.
} 


\section{Final Remarks}

This paper evaluated the impacts of GM technology adoption on the recent restructuring of the global trade of soybeans. Results show technological change impacting on the international trade of soybean trade restructuring in terms of sources and destinations. Even flows with countries that did not impose any official ban on the GM importation were affected. This fact puts non-tariff trade barriers at forefront in the matter of technology diffusion, making it clear that the "legalist" vision may be faulty. In addition, results corroborate labeling, along with low-level presence of unapproved GM material and asynchronous approval, as the most detrimental variables to trade of GMfood/feed.

When it comes to effective growth, Brazil was the only country capable of increasing its exports during all the analysis periods. Results indicate that lowers or negatives rate of growth of US exports in the first years is closely related to the technology adoption pace. Similarly, Brazilian exports growth is related to its later adoption. Argentina, in turn, achieved competitiveness gains resulting from technology adoption.

It is due to the fact that specialization in markets with lower levels of "hatred" - the case of US and Argentina - may contribute to positive competitiveness effect based on efficiency gains. Conversely, when exports are concentrated in markets with higher levels of "hatred" - the case of Brazil - the late adoption contributed to positive competitiveness effect.

However, competitiveness achieved by Brazil and Argentina was annulled after Brazil has adopted technology in the last period. As a result, United States obtained better results in this effect. Interestingly, changes in the supply structure, pushed by the Brazilian adoption of technology, did not mean a return to the old market structure in terms of sources and destination. ${ }^{31}$ It could be revealing that markets that previously rejected its technology could be no longer sustaining its markets solely with conventional soybeans.

China effect, which can be seen as a globalization effect, prevented US and Argentina incurring in greater economic losses due to early GM technology adoption.

Finally, studies analyzing behaviors of trade flows and prices in the upcoming years will be of extreme importance for the handling of this matter. They may be able to tell us whether this structure stays the same, and weather Brazil obtained any advantage by being a late adopter in terms of premium prices, or if the current trade structure is sustainable.

\footnotetext{
${ }^{31}$ Brazil still maintains a small proportion of conventional soy in production. This proportion may be sustaining demands from EU markets.
} 


\section{References}

Ahmadi-Esfahani, F. Z. (2006). Constant market shares analysis: uses, limitations and prospects. The Australian Journal of Agricultural and Resource Economics, 50(4), 510-526. doi:10.1111/j.14678489.2006.00364.x

Akerlof, G. (1970). The market for" lemons": Quality uncertainty and the market mechanism. The quarterly journal of economics, 84(3), 488-500.

Anderson, K. (2010). Economic impacts of policies affecting crop biotechnology and trade. New biotechnology, 27(5), 558-64. doi:10.1016/j.nbt.2010.05.012

Anderson, K., \& Jackson, L. A. (2004). Standards, trade and protection : the case of GMOs. Adelaide.

BIO. (2012). Biotechnology Industry Organization: Agricultural Product Database. Washington, D.C. Retrieved from http://www.biotradestatus.com/

Borges, I. de C. (2003). Biotecnologia e comercio externo : uma analise da inserção brasileira. University of Campinas.

Brossard, D., Shanahan, J., \& Nesbitt, R. C. (Eds.). (2007). The Public. The Media \& Agricultural Biotechnology (p. 405). Oxon: CABI.

Carter, C., \& Gruère, G. (2006). International approval and labeling regulations of genetically modified food in major trading countries. In R. E. ( U. of M. Just, D. Alston, Juliian M. (University of California, \& B. Zilberman, David (University of California (Eds.), Regulating agricultural biotechnology: economics ... (pp. 459-480). New York, NY: Springer New York.

Carvalho, F. (1995). O comportamento das exportações brasileiras ea dinâmica do complexo agroindustrial. 1995. São Paulo University.

CERA. (2012). GM Crop Database. Center for Environmental Risk Assessment (CERA). Washington D.C.: ILSI Research Foundation. Retrieved from http://cera-gmc.org/index.php?action=gm_crop_database

Compass, G. (2012). GMO Database. Retrieved from http://www.gmo-compass.org/eng/gmo/db/

Disdie, A.-C., \& Fontagné, L. (2009). Trade Impact of European Measures on GMOs Condemned by the WTO Panel.

FAOSTAT. (n.d.). Retrieved June 02, 2013, from http://faostat.fao.org/site/406/default.aspx

Feinberg, S. (2000). Do world product mandates really matter? Journal of International Business Studies, $31(1), 155-167$.

Gaskell, G., Stares, S., Allansdottir, A., \& Allum, N. (2010). Europeans and Biotechnology in 2010 Winds of change? (p. 170). Luxembourg.

Greenpeace. (2004). Public's perception of Genetically Engineered Food: Summary of Report. Retrieved from htpp://www.greenpeace.org.hk

Griffith, D., Hu, M., \& Ryans, J. (2000). Process standardization across intra-and inter-cultural relationships. Journal of International Business ..., 31(2), 303-324. 
Grimsrud, K. (2004). Consumer attitudes to genetically modified food in Norway. Journal of Agricultural ....

Huang, J, Yang, J., \& Yang, W. (2012). Trade and Economic Implications of Low Level Presence and Asynchronous Authorizations of Agricultural Biotechnology Varieties: A Case Study in China. In 28th International Conference of Agricultural Economists: The Global Bioeconomy (pp. 1-37). Foz do IguaçuBrazil.

Huang, Jikun, Qiu, H., Bai, J., \& Pray, C. (2006). Awareness, acceptance of and willingness to buy genetically modified foods in Urban China. Appetite, 46(2), 144-51. doi:10.1016/j.appet.2005.11.005

III, R. H., \& Kashlak, R. (1999). National influences on multinational corporation control system selection. MIR: Management International Review, 39(2), 167-189.

Isaac, G. E., Perdikis, N., \& Kerr, W. a. (2004). Cracking export markets with genetically modified crops: What is the entry mode strategy? International Marketing Review, 21(4/5), 536-548. doi:10.1108/02651330410547180

Jepma, C. J. (1986). Extensions and Application Possibilities of the Constant Market Shares Analysis: The Case of the Developing Countries' Exports (p. 257). Groningen RijksUniversity.

Leamer, E., \& Stern, R. (2006). Quantitative international economics. Journal of International Economics (p. 209). Aldine Transaction.

Madhok, A., \& Osegowitsch, T. (2000). The international biotechnology industry: a dynamic capabilities perspective. Journal of International Business ..., 31(2), 325-335.

Mccluskey, J. J., Grimsrud, K., \& Wahl, T. I. (2006). Comparison of Consumer Responses to Genetically Modified Foods in Asia, North America, and Europe. In R. Just, J. Alston, \& D. Zilberman (Eds.), Regulating agricultural biotechnology : economics and policy (p. 732). New York, NY: Springer New York.

Meyer, K. (2001). Institutions, transaction costs, and entry mode choice in Eastern Europe. Journal of international business studies, 2, 357-367.

Moschini, G. (2004). Innovation and Trade with Market Failure: The Case of Genetically Modified Products, $86(3), 634-648$.

Noussair, C., Robin, S., \& Ruffieux, B. (2002). Do consumers not care about biotech foods or do they just not read the labels? Economics Letters, 75(1), 47-53. doi:10.1016/S0165-1765(01)00594-8

Oldersma, H., \& Bergeijk, P. Van. (1993). Not so constant! The constant-market-shares analysis and the exchange rate. De Economist, 141(3), 380-401.

Oliveira, A. L. R., \& Silveira, J. M. F. J. (2013). Restructuring of the Corn Supply Chain in Brazil : Facing the Challenges in Logistics or Regulation of Biotechnology. International Food and Agribusiness Management Review, 16(4).

Oliveira, A. L. R., Silveira, J. M. F. J., \& ALVIM, A. M. (2012). Cartagena protocol, biosafety and grain segregation: The effects on the soybean logistics in Brazil. E3 Journal of Agricultural research and development, 2(1), 17-30.

Oliveira, P. R. S. (2012). Os Organismos Geneticamente Modificados e os Impactos no Comércio Internacional Agrícola: Um Estudo de Caso da Soja. University of Campinas.

Oliveira, P. R. S., Silveira, J. M. F. J., Magalhães, M. M., \& Souza, R. F. (2013). ADOPTION OF TECHNOLOGIES WITH MARKET REJECTION AND RETURN ON EXPORTS: BRAZIL, UNITED STATES, ARGENTINA AND THE CASE OF GM-SOYBEANS. In 17th ICABR Conference: “INNOVATION AND POLICY FOR THE BIOECONOMY.” Ravello - Italy. 
Paarlberg, R. (2001). The politics of precaution: genetically modified crops in developing countries. (p. 200). Whashington, DC: International Food Policy Research Institute (September 17, 2001).

PRICE. (2013). PRICE | PRactical Implementation of Coexistence in Europe. Retrieved from http://pricecoexistence.com/

Richardson, J. (1971). Constant-market-shares analysis of export growth. Journal of International Economics, 1(197 1), 227-239.

Roessing, A., \& Lazzarotto, J. (2005). Soja transgênica no Brasil: situação atual e perspectivas para os próximos anos. ... de Soja da Região Central do Brasil (p. 37). Brasília.

Rugman, A. (1976). Risk reduction by international diversification. Journal of International Business Studies, 7(2), 75-80.

Schomberg, R. von. (1998). An appraisal of the working in practice of directive 90/220/EEC on the deliberate release of genetically modified organisms.

Silveira, J. da, \& Borges, I. de C. (2007). Brazil: Confronting the challenges of global competition and protecting biodiversity. In S.-F. (New S. U. Parr (Ed.), The gene revolution: GM ... (p. 248). London: Earthscan.

Smyth, S., Kerr, W. a., \& Davey, K. a. (2006). Closing markets to biotechnology: does it pose an economic risk if markets are globalised? In International Journal of Technology and Globalisation (Vol. 2, p. 377). doi:10.1504/IJTG.2006.011923

Stein, A. J., \& Rodriguez-Cerezo, E. (2009). The global pipeline of new GM crops Implications of asynchronous approval (p. 109).

Tomich, F. A., \& Leite, C. A. M. (1999). Competitividade das exportações brasileiras de frutas selecionadas. Universidade Federal de Viçosa.

Tyszynski, H. (1951). World Trade in Manufactured Commodities, 1899-19501. The Manchester School, 19(3), 272-304. doi:10.1111/j.1467-9957.1951.tb00012.x

Vigani, M., Raimondi, V., \& Olper, A. (2012). International trade and endogenous standards: the case of GMO regulations. World Trade Review, 11(03), 415-437. doi:10.1017/S1474745612000262 


\section{Tables and Figures}

Table 1- GM Soybean events approved in EU

\begin{tabular}{llllc}
\hline \multicolumn{1}{c}{ Event } & \multicolumn{1}{c}{ Trait } & \multicolumn{1}{c}{ Company } & \multicolumn{1}{c}{ Type of Approval } & Year \\
\hline MON40-3-2 & Herbicide Tolerant & Monsanto & Feed and Food & 1996 \\
A2704-12 & Herbicide Tolerant & Bayer & Feed, Food and Processing & 2008 \\
MON89788 & Herbicide Tolerant & Monsanto & Feed, Food and Processing & 2008 \\
\hline
\end{tabular}

Source: Prepared by the authors based on information from (BIO (2012); CERA (2012); GMO Compass (2012).

Table 2 - GM Soybean events approved in Japan

\begin{tabular}{lllll}
\hline \multicolumn{1}{c}{ Event } & \multicolumn{1}{c}{ Trait } & Company & \multicolumn{1}{c}{ Type of Approval } & \multicolumn{1}{c}{ Year } \\
\hline MON40-3-2 & Herbicide tolerant & Monsanto & Food/ Feed/Production & 1996 \\
A2704-12 & Herbicide tolerant & Bayer & $\begin{array}{l}\text { Food (a) Feed (b) } \\
\text { Production (c) }\end{array}$ & $\begin{array}{l}2002 \text { (a) 2003(b) } \\
1999 \text { (c) }\end{array}$ \\
MON89788 & Herbicide tolerant & Monsanto & $\begin{array}{l}\text { Production/Feed (a) Food } \\
\text { (b) }\end{array}$ & 2008 (a) 2007(b) \\
& Herbicide tolerant & Bayer & $\begin{array}{l}\text { Production/Feed (a) Food } \\
\text { (b) }\end{array}$ & 2006 (a) 2003 (b) \\
A5547-127 & Pioneer & $\begin{array}{l}\text { Food/ Feed/Production } \\
2009\end{array}$ \\
DP356043 & Herbicide tolerant & DuPont & $\begin{array}{l}\text { Production (a) Food (b) } \\
\text { F94-1, G94- }\end{array}$ & High Oleic Acid \\
$\begin{array}{l}\text { 19, G168 } \\
\text { Source: Prepared by the authors based on information from (BIO (2012); CERA (2012); GMO Compass (2012). }\end{array}$
\end{tabular}

Table 3 - GM Soybean events approved in China (section 3)

\begin{tabular}{lllll}
\hline \multicolumn{1}{c}{ Event } & \multicolumn{1}{c}{ Traits } & Company & \multicolumn{1}{c}{ Type of Approval } & Year \\
\hline MON40-3-2 & Herbicide Tolerant & Monsanto & Food and Feed/Biosafety Certificate ${ }^{32}$ & 2004 \\
A2704-12 & Herbicide Tolerant & Bayer & Biosafety Certificate & 2007 \\
MON89788 & Herbicide Tolerant & Monsanto & Food and Feed/Biosafety Certificate & 2008 \\
\hline
\end{tabular}

Source: Prepared by the authors based on information from (BIO (2012); CERA (2012); GMO Compass (2012).

32 The Biosafety Certificate is granted after the biosafety analysis is carried out. It does not mean that approval was granted for production. 
Table 4- Destination Market Grouped (section 4)

\begin{tabular}{|c|c|}
\hline Group & Description \\
\hline UE countries & $\begin{array}{l}\text { Made up of the } 27 \mathrm{EU} \text { countries, not including the year of entrance into } \\
\text { the union. }\end{array}$ \\
\hline Other European Countries & Made up of European countries that are not part of EU. \\
\hline Japan & Japan. \\
\hline China & China and Territories (Hong Kong and Macao). \\
\hline Other Asian Countries & All Asian Countries, excluding Japan e China. \\
\hline Oceania & Made up of all Oceanic countries. \\
\hline Africa & Made up of all Africans countries. \\
\hline North America + Mexico & Canada, US and Mexico. \\
\hline Latin America & American Countries excluding North America and Mexico. \\
\hline ND & Not Declared Destinations. \\
\hline Years & Description \\
\hline 1990-1992 & Pre-Adoption Period. \\
\hline 1995-1997 & Partial Adoption Period: (US and Argentina adopt technology). \\
\hline 2000-2002 & egregated Market: (Brazil supply the market with conventional soy). \\
\hline 2004-2006 & Full Adoption Period: (Brazil adopts technology). \\
\hline 2007-2009 & Post Adoption Period. \\
\hline
\end{tabular}

Chart 1 - European and Chinese Imports of Soybean from US, Brazil and Argentina. (1990-2009) thousand tons.

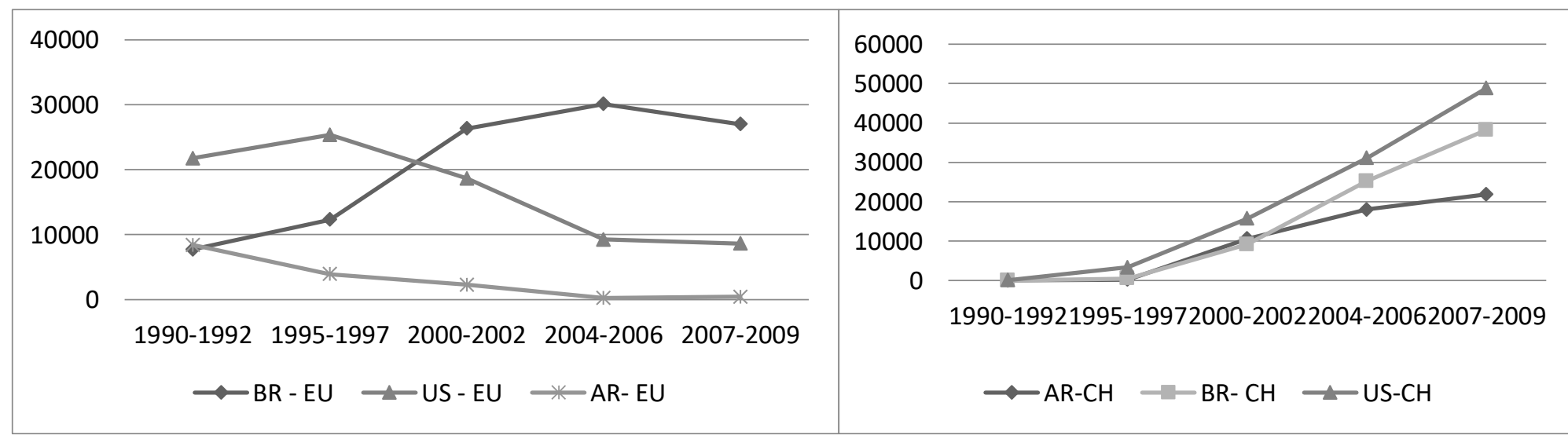

Source: Prepared by the authors based on ("FAOSTAT," n.d.) 
Table 6 - Effects for the Partial Adoption Period

\begin{tabular}{lcccccc}
\hline Periods & $\begin{array}{c}\text { Effective } \\
\text { Growth }\end{array}$ & Competitiveness & $\begin{array}{c}\text { World } \\
\text { Trade }\end{array}$ & $\begin{array}{c}\text { Destination } \\
\text { Market }\end{array}$ & $\begin{array}{c}\text { Processing } \\
\text { (replacement effect) }\end{array}$ & $\begin{array}{c}\text { Production } \\
\text { Decreases }\end{array}$ \\
\hline Brazil (I) & $57.57 \%$ & $52.79 \%$ & $51.10 \%$ & $-3.89 \%$ & No & No \\
& & & & & & No \\
Argentina (I) & $-52.66 \%$ & $151.62 \%$ & $-55.88 \%$ & $4.26 \%$ & Yes (significant) & No \\
US (I) & $44 \%$ & $38.20 \%$ & $66.89 \%$ & $-5.09 \%$ & No & No \\
\hline
\end{tabular}

Source: Prepared by the authors.

Table 7 - Effects for the Segregated Market Period

\begin{tabular}{lcccccc}
\hline \multicolumn{1}{c}{ Periods } & $\begin{array}{c}\text { Effective } \\
\text { Growth }\end{array}$ & Competitiveness & $\begin{array}{c}\text { World } \\
\text { Trade }\end{array}$ & $\begin{array}{c}\text { Destination } \\
\text { Market }\end{array}$ & $\begin{array}{c}\text { Processing } \\
\text { (replacement effect) }\end{array}$ & $\begin{array}{c}\text { Production } \\
\text { Decreases }\end{array}$ \\
\hline Brazil (II) & $178.85 \%$ & $69.47 \%$ & $27.64 \%$ & $2.89 \%$ & No & No \\
$\begin{array}{l}\text { Argentina } \\
\text { (II) }\end{array}$ & $246.42 \%$ & $77.84 \%$ & $20.06 \%$ & $2.10 \%$ & No & No \\
US (II) & $11 \%$ & $-389.30 \%$ & $442.96 \%$ & $46.34 \%$ & No & No \\
\hline
\end{tabular}

Source: Prepared by the authors.

Table 8 - Effects for the Full Adoption Period (section 5)

\begin{tabular}{lcccccc}
\hline \multicolumn{1}{c}{ Periods } & $\begin{array}{c}\text { Effective } \\
\text { Growth }\end{array}$ & Competitiveness & World Trade & $\begin{array}{c}\text { Destination } \\
\text { Market }\end{array}$ & $\begin{array}{c}\text { Processing } \\
\text { (replacement effect) }\end{array}$ & $\begin{array}{c}\text { Production } \\
\text { Decreases }\end{array}$ \\
\hline Brazil (III) & $54.39 \%$ & $67.05 \%$ & $36.95 \%$ & $-4.00 \%$ & No & No \\
Argentina (III) & $37.98 \%$ & $52.81 \%$ & $52.93 \%$ & $-5.73 \%$ & No & No \\
US (III) & $-5 \%$ & $458.43 \%$ & $-401.96 \%$ & $43.53 \%$ & Yes (moderate) & No \\
\hline
\end{tabular}

Source: Prepared by the authors.

Table 9 - Effects for the Post Adoption Period

\begin{tabular}{lcccccc}
\hline \multicolumn{1}{c}{ Periods } & $\begin{array}{c}\text { Effective } \\
\text { Growth }\end{array}$ & Competitiveness & World Trade & $\begin{array}{c}\text { Destination } \\
\text { Market }\end{array}$ & $\begin{array}{c}\text { Processing } \\
\text { (replacement effect) }\end{array}$ & $\begin{array}{c}\text { Production } \\
\text { Decreases }\end{array}$ \\
\hline Brazil (IV) & $15.24 \%$ & $-39.47 \%$ & $151.41 \%$ & $-11.94 \%$ & No & Yes $(-25 \%)$ \\
Argentina (IV) & $14.42 \%$ & $-47.34 \%$ & $159.96 \%$ & $-12.62 \%$ & No & No \\
US (IV) & $31 \%$ & $32.41 \%$ & $73.38 \%$ & $-5.79 \%$ & No & Yes $(4 \%)$ \\
\hline
\end{tabular}

Source: Prepared by the authors.

${ }^{33}$ The Argentinian case allows us to infer that a solution for market barriers may be soy processing, since the processed product has been facing reduced levels of legal restrictions. 